\title{
"How employee engagement mediates the influence of individual factors toward organizational commitment"
}

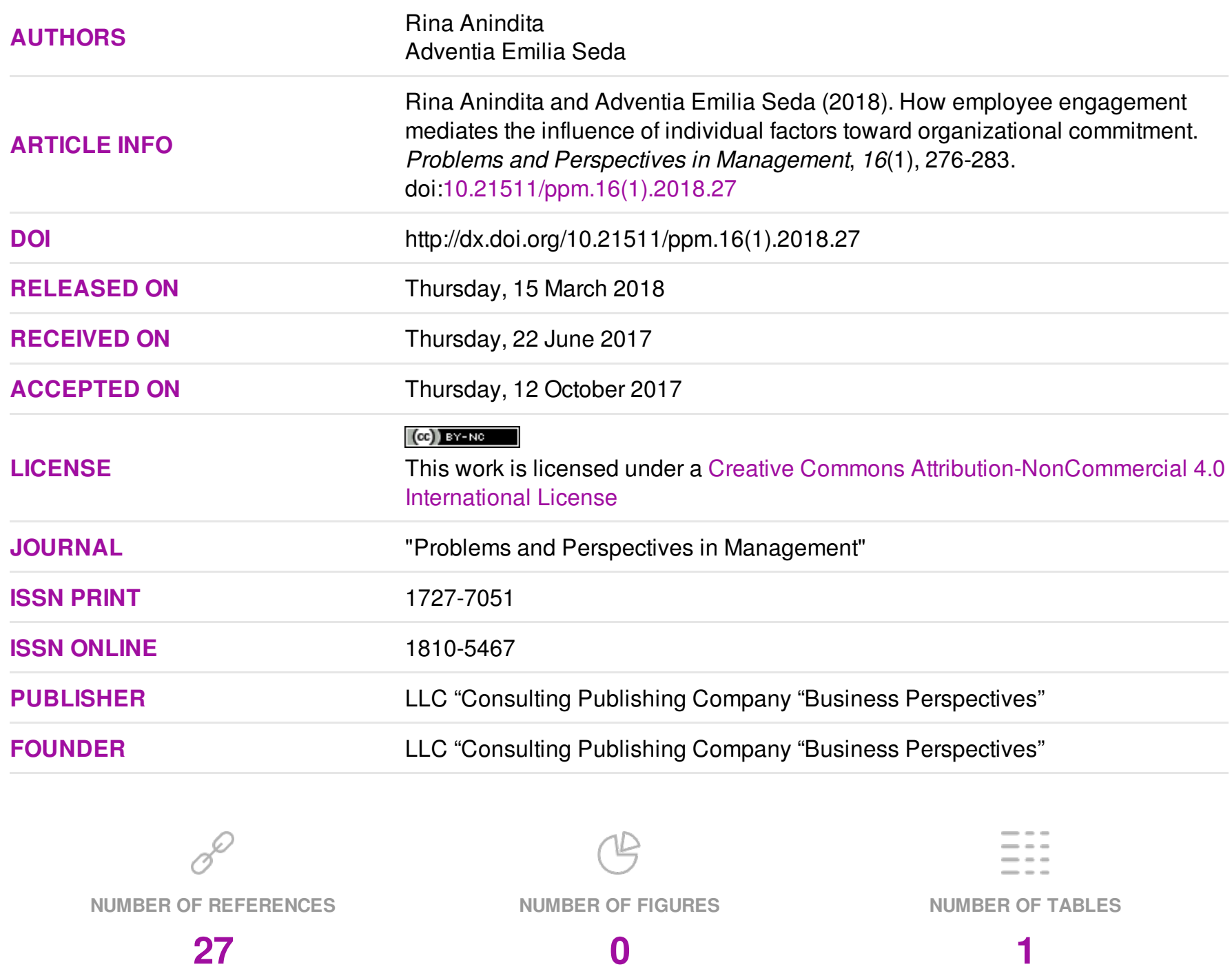

(C) The author(s) 2022. This publication is an open access article. 


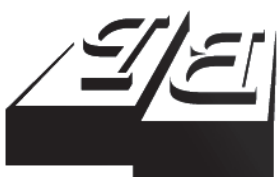

BUSINESS PERSPECTIVES

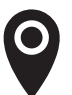

LLC "CPC "Business Perspectives" Hryhorii Skovoroda lane, 10, Sumy, 40022, Ukraine

www.businessperspectives.org

Received on: $22^{\text {nd }}$ of June, 2017 Accepted on: $12^{\text {th }}$ of October, 2017

(C) Rina Anindita, Adventia Emilia Seda, 2018

Rina Anindita, Lecturer, Faculty of Economic and Business, Esa Unggul University, Indonesia.

Adventia Emilia Seda, Graduate Student, Faculty of Economic and Business, Esa Unggul University, Indonesia

\section{HOW EMPLOYEE ENGAGEMENT MEDIATES THE INFLUENCE OF INDIVIDUAL FACTORS TOWARD ORGANIZATIONAL COMMITMENT}

\begin{abstract}
Employee engagement affects the Employer Commitment which has influence on the expression desired by someone in relation to their professional attitude, connecting the work with personal life for phychological, cognitive, emotional, and their personal feelings as a whole, so that employees engagement towards a company will drive the employees' performance. This is proved by the previous studies, but they have not included individual factors as the force that forms employee engagement or organizational commitment, specifically because seeing how the consequences of employee engagement produced. In this study, the authors consider the influence of individual factors towards organizational commitment mediated by employee engagement, which distinguishes this study from the previous ones. The objectives of this study are: first, to discover how individual factors affect employee engagement; second, to find out how employee engagement affects Organizational Commitment of employees; Third, to discover how individual factors affect organizational commitment. This study is conducted among the respondents all of whom are employees within MICE industry in Indonesia using questionnaire. Data analysis in was performed this study using Structural Equation Modeling (SEM) method. The results of this study show that high individual factors will form high employee engagement, high employee engagement will form high organizational commitment, and high individual factors will form high organizational commitment. In this study, it is found that there is an influence of individual factors towards organizational commitment mediated by employee engagement.
\end{abstract}

Keywords

individual factors, employee engagement, organizational commitment, MICE industry, Indonesia

\section{JEL Classification M12, M51, M54, M50}

\section{INTRODUCTION}

Human Resources (HR) practitioners consider employees as the most important asset in an organization, they are considered to have a role in supporting the achievement of organization's goals. Employee Engagement and Organizational Commitment are variables that have a role in increasing the employees' performance in achieving their goals (Markos \& Sridevi, 2010; Jaros, 2007; Meyer \& Allen, 1997; Metha \& Metha, 2013). In this case, with the existence of Employee Engagement, employee will have commitment towards the company so that employees are driven and enthusiastic in performing their jobs. The consequence of strong Employee Engagement is Organizational Commitment (Saks, 2006). The great influence of Employee Engagement and Organizational Commitment towards the company's performance is what intrigued the researchers to discuss further about it, especially in support of the employees' performance within a company at developing stage and at international scale. A company in its developing stage is in need for employees' with a high Employee Engagement characteristic, as well as a strong 
Organizational Commitment to continue adapting to changes and new innovation in order to implement the company's strategy (Zulkarnain \& Hadiyani, 2014).

Ortiz and Lau (2011) showed how Employee Engagement is related with other dimensions' existing in Organizational Commitment. In their study, it is found that Employee Engagement does not have a positive and significant relation with Continuance Commitment, yet has a positive relation with Normative Commitment. Ologbo and Sofian (2012) in their study showed all three Individual Factors which are Employee Communication, Employee Development, and Co-Employee Support have a positive impact on Employee Engagement. In their study, Employee Engagement can mediate Individual Factors and consequences resulted, which are Organizational Commitment, OCB (Organizational Citizenship Behavior), and Turnover Intentions.

Prasanna and Swarnalatha (2012) in their study showed that Organizational Commitment can be formed with Goal Setting, Employee Engagement and optimism towards the company. However, it can be created if all three have been greatly implemented, which are creating goal setting between employees and the management so that the employees feel included in every work performed. Therefore, the cooperation leads to employees' commitment and optimism in working, these are what support the increase of employees' commitment towards their organization.

The previous studies have not included the specific influence of Individual Factors on neither Employee Engagement nor Organizational Commitment. The previous studies which included the Individual Factors measured Employee Engagement consequences produced, which were Organizational Commitment, $\mathrm{OCB}$, and Turnover Intentions, yet not specifically on Organizational Commitment. Therefore, we include the effects of Individual Factors towards Organizational Commitment mediated by Employee Engagement (Job Engagement and Organizational Engagement), in which differentiate this from the previous studies.

The objectives of this study are: first, to discover how Individual Factors affect Employee Engagement in MICE industry; second, to find out how Employee Engagement (Job Engagement and Employee Engagement) affects Organizational Commitment of employees in MICE industry; third, to discover how Individual Factors affect Organizational Commitment of employees in MICE industry.

\section{LITERATURE REVIEW}

\subsection{Individual factors}

In their study, Robinson et al. (2004) state that the most powerful stimulus in creating Employee Engagement is the existing of significant feeling and inclusiveness as a whole among employees. There are several things which can create this component among employees, they are: first, presence of employee's involvement in decision making; second, employees feeling free to express their opinion and in this case, the supervisor listening to their point of view so that the employees feel that they have contributed towards the company; third, employees are given opportunity to develop in relation to their job; fourth, organization gives special attention to the welfare and health of the employees. Several points mentioned before were also stated by Ologbo and Sofian (2013) who categorized stimuli or antecendents of Employee Engagement into two things: Individual Factors of Employee Engagement and Organizational Factors of Employee Engagement. The Individual Factors meant in Employee Engagement are the stimuli or antecedents, which can motivate employees individually to perform their function in their work so that they can be fully involved in the job effectively and efficiently. While what was meant with Organizational Factors were stimuli or antecedents formed within organization to urge the employee performance implementation. Saks (2006) mentioned that it is important to provide encouragement which can motivate the employees directly in order for them to perform their function in the work effectively and efficiently so that they can be 
fully involved in their job. Hence, the researchers notice and focus on the encouragement through Individual Factors first. As for several Individual Factors, they are Employee Communication, Employee Development, and Co-employee Support.

\subsection{Employee Engagement}

Kahn (1990) defined Employee Engagement as the commitment of employee personally to the role and responsibility in work. In this case, individual used their psychological, cognitive, and emotional feeling to provide an optimum performance in implementing their responsibilities within the work. Furthermore, Harter et al. (2002) defined Employee Engagement as the individual's involvement and satisfaction, as well as enthusiam for work. Hence, Employee Engagement is a level of commitment and employee's involvement in an organization and the values within. Employee Engagement is the employee's willingness and ability to contribute directly to the company's succees continously. Commitment towards the organization is deeply affected by several factors both emotionally or rationally, are which directly related to the work and work experience (Global Perrin/Perrin's Global Workforce Study, 2003). Robinson et al. (2004) defined Employee Engagement as employee's positive attitude towards the company they work for and also the company's values. Meanwhile, Saks (2006) defined Employee Engagement based on how far individuals provide their full attention in performing the role they have. Therefore, it is concluded that Employee Engagement is the will and positive attitude of an employee by giving special attention to contributing directly in performing their roles.

\subsection{Organizational Commitment}

Allen and Meyer (1991) formulated Organizational Commitment as a psychological form of relations between employee and their organization, and which has a strong influence on whether or not the employee will stay with the organization. This is also supported by Meyer and Herscovitch (2001) who say that commitment is an individual strength in doing something according to the goals of the company. Mowday et al. (1997) defined Organizational Commitment (OC) as a multidimensional concept, whichis able to make the employee do something on behalf of the company, by believing in and accepting the values and goals of an organization. Organizational Commitment is a level where someone position themselves within an organization and have willingness to continue the effort in achieving the organization's objectives (Noe, 2000). Organizational Commitment is also defined as employee's circumstances in siding and supporting an organization including its objectives, and also has the intention to nurture its membership within the said organization (Robinson et al., 2006). It is concluded that Organizational Commitment is a psychological relation between employees and their organization by accepting and carrying out the objectives set, as well as having a strong influence on staying with the organization.

\section{VARIABLES RELATIONSHIP AND HYPOTHESES DEVELOPMENT}

Positive attitude produced by employees will emerge if there are several supporting factors, one of which is Individual Factors namely Employees Communication, Employees Development, and Co-employees Support. With good communication among employees, it can increase the sense of involvement, because they feel heard and contributing in providing opinions on problem solving. Employee development can make employees feel more supported because they are given the opportunity to develop their ability and skills. Meanwhile, support from co-workers makes the employees collectively and collaboratively involve in achieving the goals, so the employees feel contributive. This creates Employee Engagement among the employees. High Employee Involvement can increase Employee Engagement and vice versa, employees who are not involved in discussion and interaction in a company, have low Employee Engagement. Therefore, it is important for employees to have Employee Engagement in executing their work, because employees with high Employee Engagement are more energized in performing their job (Bakker \& Leiter, 2010).

Robinson et al. (2004) showed all four things within the impetus category for the creation of Employee Engagement. The existence of good communi- 
cation among employees can create trust to one another, similarly with Employee Development and also Employee Collaboration in each level. The significant feeling and commitment among employees becomes a part of Individual Factors, which enable to produce Employee Engagement. The higher Individual Factors for employees, the higher Employee Engagement is formed (Ologbo \& Sofian, 2012).

From the above argument, the researcher proposed the hypothesis:

\section{H1: Good Individual Factor will create high Employee Engagement.}

Employee with high Employee Engagement will have a positive gesture in the work and will be involved in the achievement of organization. In this case, Employee Involvement causes doing something for the sake of achieving objectives of the company. It is in tune with Organizational Commitment where individuals with Organizational Commitment have a positive psychological connection between employees and their organization so that the employee will implement the organization's objectives and accept them. It can be said that an employee with high Employee Engagement will have better Organizational Commitment, and also vice versa, employee with low Employee Engagement or careless will be followed by low Organizational Commitment too. Organizational Commitment creates a level where someone positioned themselves within the organization and have the willingness to continue the effort of achieving the organization's goals (Noe, 2000).

In Saks' (2006) research, it is also found that Job and Organizational Engagement mediated connection between the antecedentsandEmployee Engagement consequences which are Work Satisfaction, Organizational Commitment, Intentions to leave, and Organizational Citizenship Behavior. Based on the analysis, Employee Engagement has an influence towards Organizational Commitment. The higher Employee Engagement owns, then the higher the Organizational Commitment.

From the above analysis, the researcher proposed the hypothesis:
H2: High Employee Engagement will produce high Organizational Commitment.

In this study, the researchers (Gallup, 2005; Saks, 2006) also wanted to see how Individual Factors can affect Organizational Commitment of employees. This is considered important for researchers, because several antecedents proposed by Meyer and Allen (1990) have a close connection with Individual Factors referred too. Yet, researchers have not found in previous studies how Individual Factors affect the Organizational Commitment of employees. Meyer and Allen (1990) formulated three forms of Organizational Commitment, which are: Affective Commitment, Normative Commitment, and Continuance Commitment, they have several antecedents related to Individual Factors including related to communication among employees belonging to role clarity and goal clarity antecedents. First, participation (employees have good communication so that have clear information about roles and goals, they may participate directly in company's objectives). Further, those related to employee's development belong to skill and education antecedents (employees are given an opportunity to expand their skills and knowledge). And the last of Individual Factors is Co-employees Support belonging to Organizational Commitment antecedent which is peer cohesion (the existence of good co-operation between colleagues). With the study mentioned, it supports the influence of Individual Factors and Organizational Commitment on employees. Thus, the researchers offered the hypothesis that expecting high Individual Factors from employees will resulting in high Organizational Commitment too.

From the above arguments, the researcher proposed the hypothesis:

\section{H3: Good Individual Factors will create high Organizational Commitment as well.}

\section{RESEARCH METHODOLOGY}

We performed the research on the employees of PT Indonesia International Expo. The researched aspects are Individual Factors, Employee Engagement, and Organizational Commitment. 
Research is done in December 2016 with the help of survey method. This study is descriptive analysis, with causality model or related to effect. Data collection is performed by distributing the questionnaire among all employees of PT Indonesia International Expo. Data are analyzed using Structural Equation Modeling (SEM) method, also known as Analysis of Moment Structures. Deciding the number of samples for SEM, according to Hair et al. (2008), depends on the number of indicator. However, due to insufficient number of population to achieve that, the researchers decided to used other alternative. In this case, Hair et al. (2008) also stated that the sample size, according to SEM, is around 100200 samples. Data collected are then measured by Likert scale (from one to four).

In this study the researchers wanted to see the correlation between Individual Factors (antecedent's Employee Engagement) with Employee Engagement, Employee Engagement with Organizational Commitment. Based on the structure of those connections, the researchers also wanted to know the role of Employee Engagement as mediator in the relation between Individual Factors and Organizational Commitment. The variables measurement of Employee Engagement using indicators based on Saks (2006) is based on nine indicators, Individual Factors variables adapted from Robinson et al. (2004) is based on ten indicators, and Organizational Commitment variables using indicators based from Allen et al. (1993) is based on 18 indicators, then all indicators went through validation test and reliability test.

\section{RESEARCH FINDINGS}

In using SEM analysis, we also have to see compatibility of the whole model (goodness of fit). Based on that analysis, it is found that almost all results are compatible in good fit. This indicated that good fit is the result of compatibility in accordance with the values referred, while marginal fit is the result of compatibility under the values referred. Several tests were done in order to show sufficient compatibility, they were Chi-Square, RMSEA, ECVI, AIC, and CAIC, Fit Index and goodness of fit. There is a marginal fit result for Critical N. From the abovementioned results, it can be concluded that goodness of fit model is qualified
Table 1. Hypotheses testing results

\begin{tabular}{c|l|c|l}
\hline Hypotheses & $\begin{array}{l}\text { Hypotheses } \\
\text { statement }\end{array}$ & T-value & Details \\
\hline $\mathrm{H} 1$ & $\begin{array}{l}\text { High Individual } \\
\text { Factors will create high } \\
\text { Employee Engagement }\end{array}$ & 8.13 & $\begin{array}{l}\text { Data } \\
\text { support the } \\
\text { hypothesis }\end{array}$ \\
$\begin{array}{l}\text { High Employee } \\
\text { Engagement will create } \\
\text { Engh Organizational } \\
\text { high } \\
\text { Commitment }\end{array}$ & 5.27 & $\begin{array}{l}\text { Data } \\
\text { Support the } \\
\text { hypothesis }\end{array}$ \\
$\begin{array}{l}\text { High Individual } \\
\text { Factors will create } \\
\text { high Organizational } \\
\text { Commitment }\end{array}$ & 5.06 & $\begin{array}{l}\text { Data } \\
\text { Support the } \\
\text { hypothesis }\end{array}$ \\
\hline $\mathrm{H} 3$ & & &
\end{tabular}

\section{DISCUSSION}

Result of the first hypothesis $\left(H_{1}\right)$ testing shows that results of the analysis support the $H_{1}$ hypothesis, which means that there is an influence of Individual Factors on Employee Engagement by 9.13 . This showed that the higher someone's Individual Factors, the higher their Employee Engagement. The result of this study is concomitant with the previous study by Ologbo and Sofian (2012) showing that Individual Factors has a positive influence on Employee Engagement. Therefore, it also showed that all three things were impetuses in forming Employee Engagement (Robinson et al., 2014). Individual Factors a affecting the formation of Employee Engagement are Employee Communication, Employee Development, and Co-employee Support. In this case, employee with a good Employee Communication tends to easily adapt to work in an organization. Good communication among employees also generates trust and commitment to one another. The same with development of employees and support by colleagues can construct the feeling of significance and commitment among employees which formulated the occurence of Employee Engagement itself.

Result of the second hypothesis $\left(H_{2}\right)$ testing shows that result of the analysis support the $\mathrm{H}_{2}$ hypothesis, which means there exists influence of Employee Engagement on employees' Organizational Commitment by 5.27. This showed that employees' Organizational Commitment is affected by the level of Employee Engagement they have. The higher someone's Employee Engagement, the higher their Organizational Commitment created among employees. This result is concomitant with the previous study by Saks (2006) who showed the existence of positive relationship between Employee 
Engagement and Organizational Commitment. In his study, Job and Organization Engagement mediated consequences from Employee Engagement, which is Organizational Commitment.

Other studies by Albdour and Altaraweh (2014) also showed the presence of influence of someone's Employee Engagement on their Organizational Commitment. When employees feel committed both to their work and organization, they tend to have psychological emotional power in their work, which happens in an organization through a positive experience in the work. Therefore, commitment showed an influence on the said employee. Besides, employees' commitment tend to make the employees instill the organization's values or to accept certain policies in the work and to form the commitment to stay with the company. In this case, Employee Engagement consists of two dimensions: Job Engagement and Organizational Engagement, which will produce Organizational Commitment on employees through a positive work experience, they feel committed towards their roles within the said organization, psychological commitment and becoming part of the organization.

Result of the third hypothesis (H3) testing, shows that results of the analysis support the $\mathrm{H} 3$ hypothesis that there exists influence of Individual Factors on Organizational Commitment by 5.06 . It showed that Organizational Commitment is affected by someone's Individual Factors. The higher one's Individual Factors, the higher the Organizational Commitment produced. The previous study by Ologbo and Sofian (2013) showed the relationship between Individual Factors and Organizational Commitment, which is the consequence of the Employee Engagement owned.
Employees with high Individual Factors have high Organizational Commitment. This is caused by Individual Factors formed within by the presence of Employees Communication, Employees Development, and Co-employees Support. The existence of good communication among employees causes them to be given the opportunity to express their opinions in organization's problem solving so that employees do something for their company/organization. Meanwhile, Employees Development can create the feeling of significance, becoming a part of the organization, thus producing a psychological bond towards the organization. Next is the Co-employees Support, which cause the employees to work collectively and collaboratively, assist others in finishing the work in an optimum way so that the employees position themselves with the organization and have the willingness to achieve the company's objectives together.

This study also performed variables analysis; the result of hypothesis testing showed the influence of Employee Engagement's mediation variables on variables of Individual Factors and Organizational Commitment's variables. Mediation variables on Employee Engagement were used as a link between Individual Factors and Organizationl Commitment. Based on the analysis mentioned, it is known that Employee Engagement can mediate Individual Factors and Organizational Commitment. Individual Factors have a direct effect on Organizational Commitment and also Individual Factors can have indirect effect on Organizational Commitment through mediating the Employee Engagement. It can be said as partial analysis mediation, because it can have both direct and indirect effects.

\section{CONCLUSION}

There are three results found in this study. The first is Individual Factors influencing Employee Engagement positively and significantly. This means the first hypothesis is accepted, which means that high Individual Factors can affect high Employee Engagement. By the increase of Employees Communication, Employee Development and Co-employees Support will cause the feeling of significance and commitment of the employees both in their work and in the organization so that it is forming Employee Engagement. The next result shows that Employee Engagement can influence Organizational Commitment significantly and positively. This indicates that employees with high Employee Engagement tend to have high Organizational Commitment too. In this case, the second hypothesis is accepted. This 
is because when employees feel committed both to their work and the organization; they tend to have a psychological emotional power in the work in which it happens in an organization through a positive work experience, to embed the company's values, and to form a commitment to stay with the company. The third hypothesis from this study is that Individual Factors affect Organizational Commitment. High Individual Factors can cause the employees to have high desire in participating in every activity of the company, strong willingness to stay and contribute for the improvement of the organization.

It is also found that Employee Engagement can mediate between the Individual Factors and Organizational Commitment. In this case, the Individual Factors directly affect Organizational Commitment, and Individual Factors may also have indirect influence on the Organizational Commitment through the mediation of Employee Engagement. This can be described as a partial mediation analysis, because it can affect both directly and indirectly.

\section{LIMITATIONS}

This study has several limitations which can be considered for future study. This study is specifically performed on a developing company. Therefore, all policies and activities related to the formation of Individual Factors, Employee Engagement, and Organizational Commitment are not stable and are considered as a special program of the company so that there is a possibility of having different results in the future studies. Further, this study only used questionnaire as a data collection instrument. Hence, there is a possibility of bias in the answers obtained from respondents if the respondents were not answering the truth or just filling out the questionnaire based on ideal condition only. And there are no support data to go deeper on the reasoning behind their answers during the interview. This causes the measuring conducted to be less depicting the actual condition of the employees. There is also a limitation in the driving factors variables of the Employees Engagement and Organizational Commitment's formation used. The study only perceived from Individual Factors, which are Employees Communication, Employees Development, and Co-employees Support, while there are other factors that can be used as stimulant to the formation of Employee Engagement and Organizational Commitment.

\section{SUGGESTION FOR FUTURE STUDY}

For further study, this study is still very limited, because it was only carried out on certain subjects, namely the MICE industry and the newly emerged companies. Therefore, the researchers suggested that further studies should also be performed on the other service companies or on industrial manufacturing companies and on the company which are mature enough in order to obtain more objective and representative results with broader coverage. In addition to the development of the study, it is suggested to perform future study to add other variables which affect Employee Engagement and Organizational Commitment. This is because there are many other variables besides Individual Factors that can optimize these variables.

\section{REFERENCES}

1. Agyemang, C. B., Ofei, \& Batchison, S. (2013). Employee Management and Organizational Commitment: A Comparative Study of Private and Public Sector Organizations in Grana. European Journal of Business and Innovation Research, 1(4), 20-33.
2. Albdour, A. A., \& Altarawneh, I. I. (2014). Employee Engagement and Organizational Commitment: Evidence from Jordan. International journal of business, 19(2), 192-212. Retrieved from https:// www.craig.csufresno.edu/ijb/Volumes/Volume\%2019/V192-5.pdf
3. Allen, N. J., Meyer, J. P., \& Smith, C. A. (1993). Commitment Organizational and Occupations: Extension and Tes of Three Component Conceptualization. Journal of Applied Psychology, 78, 538-551. http://dx.doi. org/10.1037/0021-9010.78.4.538 
4. Allen, N. J., \& Meyer, J. P. (1991). The Measurement and Antecedents of Affective, Continuance and Normative Commitment to the Organizational. Journal of Occupational Psychology, 63(1), 1-18.

5. Azwar, S. (2012). Penyusunan Skala Psikologi. Edisi II. Yogyakarta: Pustaka Pelajar.

6. Bakker, A. B., \& Leiter, M. P. (Eds). (2010). Work Engagement: A handbook of essential theory and research. New York, NY: Psychology Press.

7. Gallup Organization (2005). Employee Engagement: The Engagement side of the Human Sigma Equation. Retrived from www. gallup.com

8. Khalid, A., \& Khalid, S. (2015). Relationship between Organizational Commitments, Employee Engagement, and Career Satisfaction A Case Of University of Gujrat, Pakistan. J. S. Asian Stud.

9. Hair, Anderson, Tatham, \& Black (2008). Multivariate. Data Analysis Fifth Edition. USA: Prentice Hall International Inc.

10. Harter, J. K., Schmidt, F. L., \& Hayes, T. L. (2002). Business-unit-level. Relationship Between Employee Satisfaction, Employee Engagement, and Business Outcomes: A Meta-Analysis. Journal of Applied Psychology, 87, 258-279.

11. Jaros, S. (2007). Meyer and Allen Model of Organizational Commitment: Measurement Issues. The Icfai Journal of Organizational Behavior, 6(4), 7-25. Retrieved from https:// pdfs.semanticscholar.org/7546/2d 9094b420466ad68c404527c7b6cb3 8d040.pdf

12. Malhotra, N. K. (2004). Riset pemasaran: Pendekatan terapan. Jakarta: Indeks Kelompok Gramedia.
13. Markos, S., \& Sridevi, M. S. (2010). Employee Engagement: The Key to improving Performance. International Journal of Business and Management, 5(12). http://dx.doi. org/10.5539/ijbm.v5n12p89

14. Metha, D., \& Metha, N. K. (2013). Employee Engagement: A Literature Review. Economica. Seri Management, 16(2), 208-2015. Retrieved from https://econpapers.repec.org/ article/romeconmn/v_3a16_3ay_3a 2013 3ai_3a2_3ap 3a208-215.htm

15. Meyer, J. P., \& Allen, N. (1997). Commitment in the Workplace: Toward a General Model. Human Resource Management Review, 11, 299-326.

16. Meyer, J. P., \& Herscovitch, L. (2001). Commitment in the Workplace: Toward a General Model. Human Resource Management Review, 11, 299-326.

17. Mowday, R. T., Steers, R. M., \& Porter, L. W. (1979). The Measurement of Organizational Commitment. Journal of Vocational Behavior, 14, 224-247.

18. Noe, R. A. (2000). Toward an Integrative Theory of Training Motivation: A Meta-Analytic Path Analysis of 20 Years of Research. Journal of Applied Psychology, 85(5), 678-707. Retrieved from http:// www.psychologie.uni-mannheim. $\mathrm{de} / \mathrm{cip} /$ tut/seminare_wittmann/ meta_fribourg/Colquitt_etal_2000_ MA_training_and_motivation.pdf

19. Ologbo, A. C., \& Sofian, S. (2012). Individual Factors and Work Outcomes of Employee Engagement. Procedia - Social and Behavioral Sciences, 40, 498-508.

20. Ologbo, A. C., \& Sofian, S. (2013). Individual and Organizational Factors of Employee Engagement on Employee Work Outcomes. In- ternational Journal of Business and Behavioral Sciences, 3(3).

21. Ortiz, D. C., \& Lau, W. K. (2011). The Effect of Employee Engagement on Continuance and Normative Commitment to the Organization. Marshall University, Marshal Digital Scholar Management Faculty Research Management, Marketing, and MIS.

22. Perrin, T. (2003). Working Today: Understanding What Drives Employee Engagement. The 2003 Towers Perrin Talent Report U.S. Retrieved from http://www.towersperrin.com/tp/getwebcachedoc

23. Robinson, D., Perryman, S., \& Hayday, S. (2004). The Drivers of Employee Engagement. Report 408 Institute for Employement Studies, UK.

24. Saks, A. M. (2006). Antecendents and Consequences of Employee Engagement. Journal of Managerial Psychology, 21(6), 600-619.

25. Shoko, M., \& Zinyemba, A. Z . (2014). Impact of Employee Engagement on Organizational Commitment in National Institutions of Higher Learning in Zimbabwe. International Journal of Advance Research, 3(9), 255-268. Retrieved from http://www.garph.co.uk/ IJARMSS/Sep2014/21.pdf

26. Swarnalatha, C., \& Prasanna, T. S. (2012). Increasing Organizational Commitment of Employees: By Correlation of Goal Setting, Employee Engagement and Optimism in the Organization. International Journal of Advances in Management and Economics, 1(6), 40-44.

27. Zulkarnain, \& Hadiyani, S. (2014). Peranan Komitmen Organisasi dan Employee Engagement terhadap kesiapan Karyawan untuk Berubah. Jurnal Psikologi, 41(1), 17-33. 